\title{
Fun, Frolic and Shakespeare: Kalyani Ishtyle
}

Sarbani Chaudhury

\section{(2) OpenEdition}

\section{Journals}

Electronic version

URL: http://journals.openedition.org/shakespeare/3417

DOI: 10.4000/shakespeare.3417

ISSN: 2271-6424

\section{Publisher}

Société Française Shakespeare

\section{Electronic reference}

Sarbani Chaudhury, «Fun, Frolic and Shakespeare: Kalyani Ishtyle », Actes des congrès de la Société française Shakespeare [Online], 33 | 2015, Online since 10 October 2015, connection on 08 June 2020 URL : http://journals.openedition.org/shakespeare/3417 ; DOI : https://doi.org/10.4000/shakespeare. 3417

This text was automatically generated on 8 June 2020 .

(c) SFS 


\title{
Fun, Frolic and Shakespeare: Kalyani Ishtyle
}

\author{
Sarbani Chaudhury
}

1 For the metropolitan English students and academics of India, Shakespeare has long been a curious blend of the venerable and the malleable but "the Bard" - as he is deferentially referred to in many Indian classrooms even today - still means serious business in the suburbia with only occasional exceptions to the rule. ${ }^{1}$ One such exception has been in place since 2008 during Radix, the annual reunion (first held in 1964) of the Department of English, University of Kalyani (established in 1960), a smalltown university in the state of West Bengal, India. On such occasions, the insidious seepage of high voltage Indi-pop, ${ }^{2}$ Bolly/Holly ${ }^{3}$ dance numbers into the culturally admissible recitals of classical dance, music, and Tagore songs and poems is reflected in the highpoint of the day's festivities - the performance of a raunchy, risque and impudently abridged version of any one Renaissance drama including those written by Shakespeare. ${ }^{4}$ This article proposes to convey an idea of the tenor and direction of such translations and performances by focusing on the most audacious production so far Macbeth: A Comedy - performed on 10 March 2012 under the able tutelage of a young faculty, Sandip Mandal.

2 The complete collectivization of the page-to-stage process - from script writing to the final performance - undermines irrevocably any hegemonic claim of the author over his own creation. Mandal prepares the working script that is continuously honed, toned and fleshed out with contributions from almost every member of the Department - colleagues, interfering and voluble rehearsal audience, support staff, and of course, the entire crew. For Macbeth: A Comedy, for instance, one colleague simply usurped the task of 'blocking' the fight scenes, another whisked jackets and shawls off the backs of the staff and students to costume the production, the top scorer of the Department ransacked the internet for background scores, continuous improvisations altered the script daily, while Lady Macbeth gamely suggested the substitution of smelling salt with her own unwashed socks for reviving Macbeth when he faints on encountering Banquo's ghost. From the first 
reading of the script, through the heartbreaks or glee at being 'cast out' or 'cast in,' letting down the guard during tea breaks and post-rehearsal flirting-cum-planning, to last minute on-stage hits, misses, and improvisations, the production takes shape through a chaotic osmosis of collective inputs which, in effect, de-privatise and decapitalise the end product celebrating its glorious hybridity.

\section{Script}

Juxtaposition as a conscious strategy is evident in the brutally truncated nine-page, sixscene version of Shakespeare's shortest tragedy that inserts select Shakespearean lines and passages in a boisterous Bengali script revelling in political incorrectness. Such decontextualised parenthetical relocation both subverts and debunks the serious and the poetic as instanced in scene V (Figure 1). As the news of Lady Macbeth's death reaches Macbeth while frolicking with a witch, he takes a brief 'time out' to deliver a truncated version of the "She should have died hereafter" speech, breaking off abruptly after "the last syllable of recorded time" (5.5.16-20), ${ }^{6}$ to apologetically admit to the bemused witch the need for such decorous soliloquies of grief before returning to his revelries.

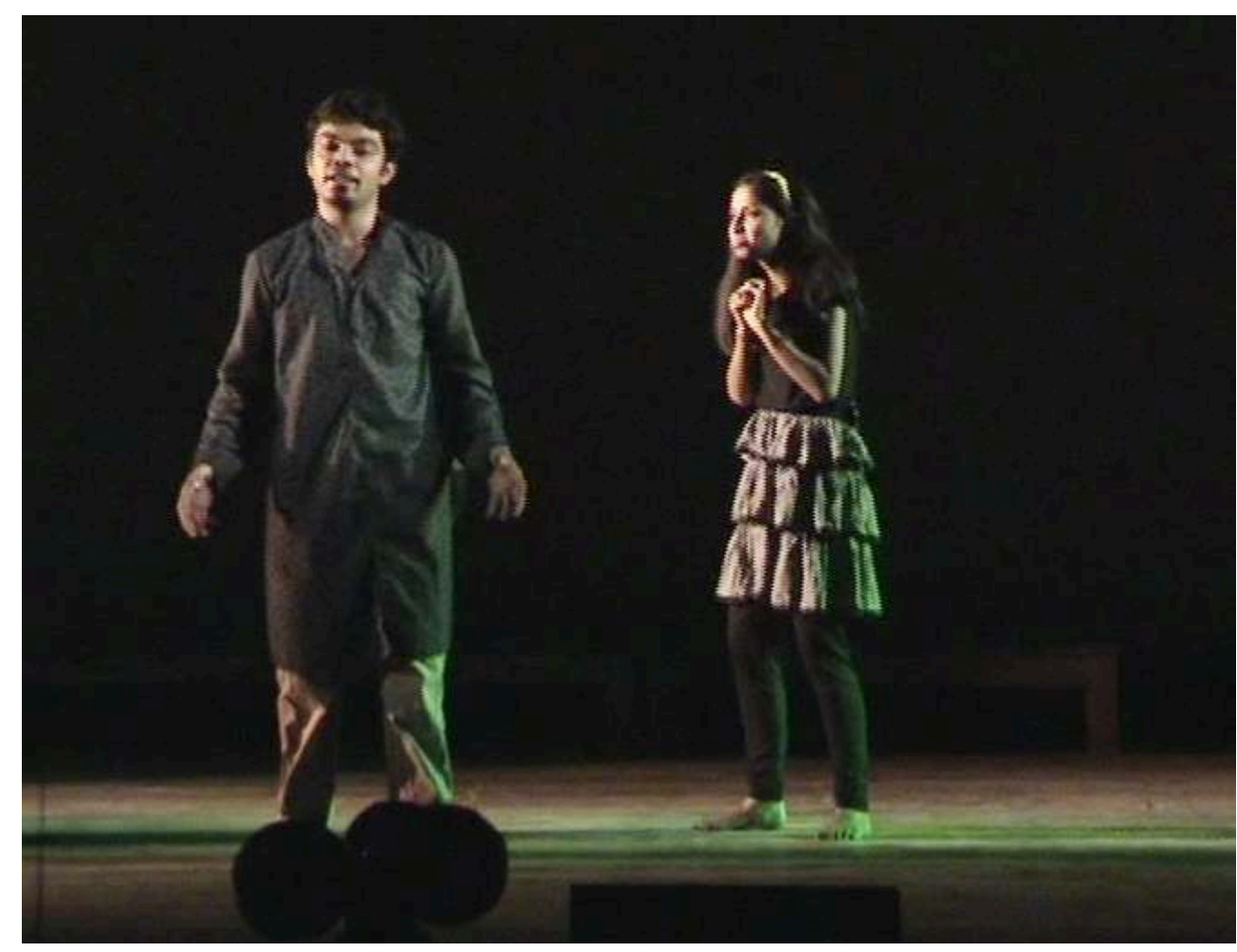

Figure 1: Macbeth (Animesh Biswas) takes a break from his revelry with the witch (Sneha Bannerjee) to mourn the death of Lady Macbeth with a truncated version of "She should have died hereafter" in scene $\mathrm{V}$.

Radix 2012, Macbeth: A Comedy, 10 March 2012, screen grab (DVD).

STUDENTS OF THE ENgLISH DEPARTMENT, UNIVERSITY OF KALYANI (DVD 2012).

Similar self-reflexive undermining of supposedly 'high brow' Shakespearean passages is facilitated by the spatiotemporal shift from the classroom and class hours to 'Reunion' time and stage which culminates with the cocking of a Bakhtinian finger at Shakespeare by the weary teachers and burdened students alike. The last scene (VI), 
situated in hell, opens with the Porter cataloguing for audience benefit, a veritable mise-en-scène of Shakespeare pedagogy, criticism and plays, ridiculed by the performance to generate an "aesthetic shock":

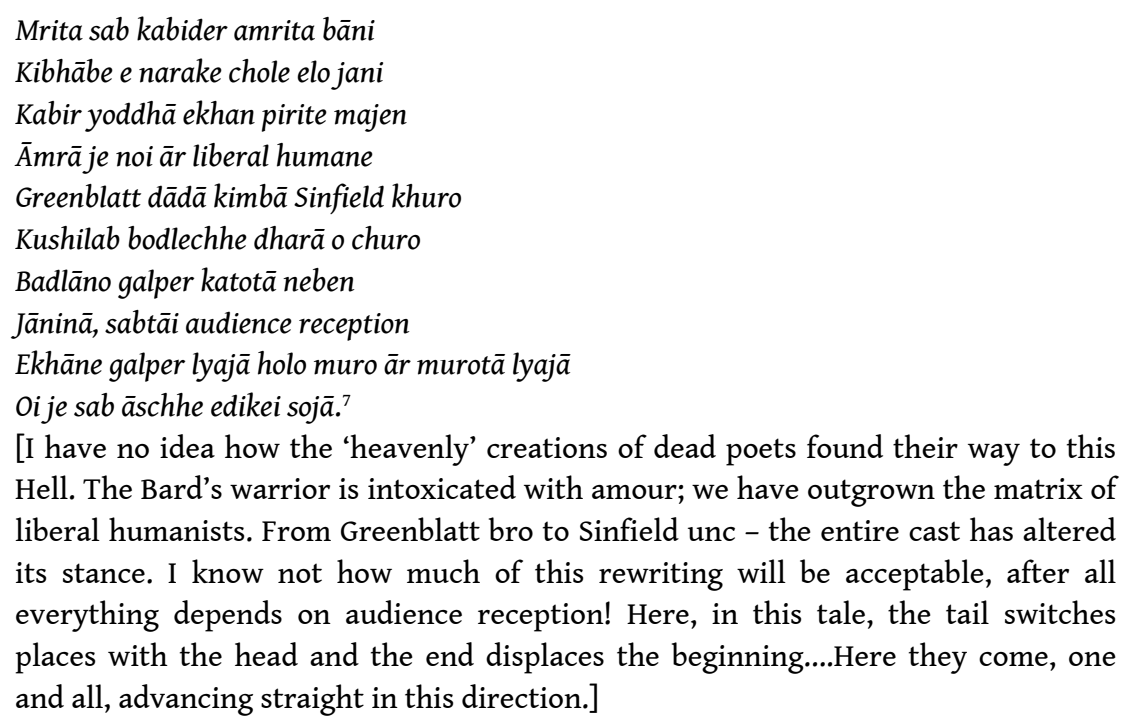

Thus Greenblatt and Sinfield join hands with the Radix family as undertakers to put liberal humanist criticism to rest, the Porter's 'Epilogue' is paid mock tribute by slotting audience response as a facet of reception theory, and confident attention is drawn to the back to front progression of the narrative hinting not only at structural reversal but also the inversion of the perceived hierarchic relationship between the source text and the target text especially in the case of Shakespeare in a postcolonial scenario: "Here, in this tale, the tail switches places with the head and the end displaces the beginning."

5 The handful of original passages that manage to find a lucky space in the script ${ }^{9}$ not only have a hard time jostling with the populous and more frequent 'low' scenes celebrating the twenty-first century Bengali urban milieu but also suffer the indignity of devastatingly bathetic 'native' interjections. Scene I, for instance, follows the witches' first encounter with Macbeth and Banquo (1.3.1-45) fairly closely till the climactic moment of prophetic declamation which predicts his wife's imminent death to a gleeful Macbeth - "Bou tor morbe ekādashi rāte" ["Your wife shall perish on the new moon night"] - and reprimands Banquo for transgressing textual boundaries by demanding similar insights into his future, "Tor ki bou āchhe - text-e nei mention" ["Do you have a wife? The text doesn't mention any!"] (emphasis added).

6 The Bengali portions of the script are consciously bawdy and replete with sexual innuendos, in deliberate contrast to the unaltered Shakespearean passages of high drama, but instead of highlighting the superiority of Shakespearean language and scenes, the juxtaposition undermines the latter by underscoring the vibrancy and energy of the Bengali exchanges, as though showing up the staidness of Shakespeare and challenging his role as the "extralingual' ensign" of the empire. ${ }^{10}$ If translation "produces strategies of containment" as Niranjana claims, then this is a rare instance of reverse translation that subverts rather than "reinforces hegemonic versions of the colonized." ${ }^{11}$ The proportional ratio between the 'original' and the 'indigenised' in so skewed in favour of the latter that the retained Shakespearean portions such as the soliloquies take on the function of annotating the translation and the target text 
consciously interpellates Shakespeare and tutors him on modes of ideal theatrical entertainment!

7 The inter-continental linguistic tug-of-war subsists on the vexed ground of intranational interculturality typified by the profusion of 'Hinglish', 'Benglish' (Hindi + English, Bengali + English), and the previously sacrilegious but now accepted cohabitation of Tagore songs, folk tunes and Bollywood item numbers. ${ }^{12}$ The Tagore songs include "Shuno go dakhino hāwā" ["Hark, O southern wind"] and "Bhenge mor gharer chābi niye jābi ke āmāre" ["Who will break the lock on my door and take me away?"], while the folk tunes are "Mono dile nā bodhu" ["You did not give me your heart, love"] and "Rupsāgare moner mānus kāncha sonā" ["My love is like pure gold in the ocean of beauty"] in scenes IV and VI respectively. ${ }^{13}$ Two Bollywood songs, "Munni badnām hui " ["Munni is reviled"] and "Sheila ki jawāni" ["Sexy Sheila"] ${ }^{14}$ are alluded to in scene II while a snippet from the film Rajkumar, "Ājā, āyi bāhār ājā, dil hai bekarār, o mere rajkumār, tere bin rahā na jāi" ["Spring is in the air and I feel so lonesome, oh do hurry my prince, I pine for you"], ${ }^{15}$ is hummed by Lady Macbeth in scene IV. The resultant intertextuality is best exemplified in Macbeth's endearing reference to his wife as "Munni" and "Sheila" in scene II that extends far beyond textual boundaries (Figure 2).

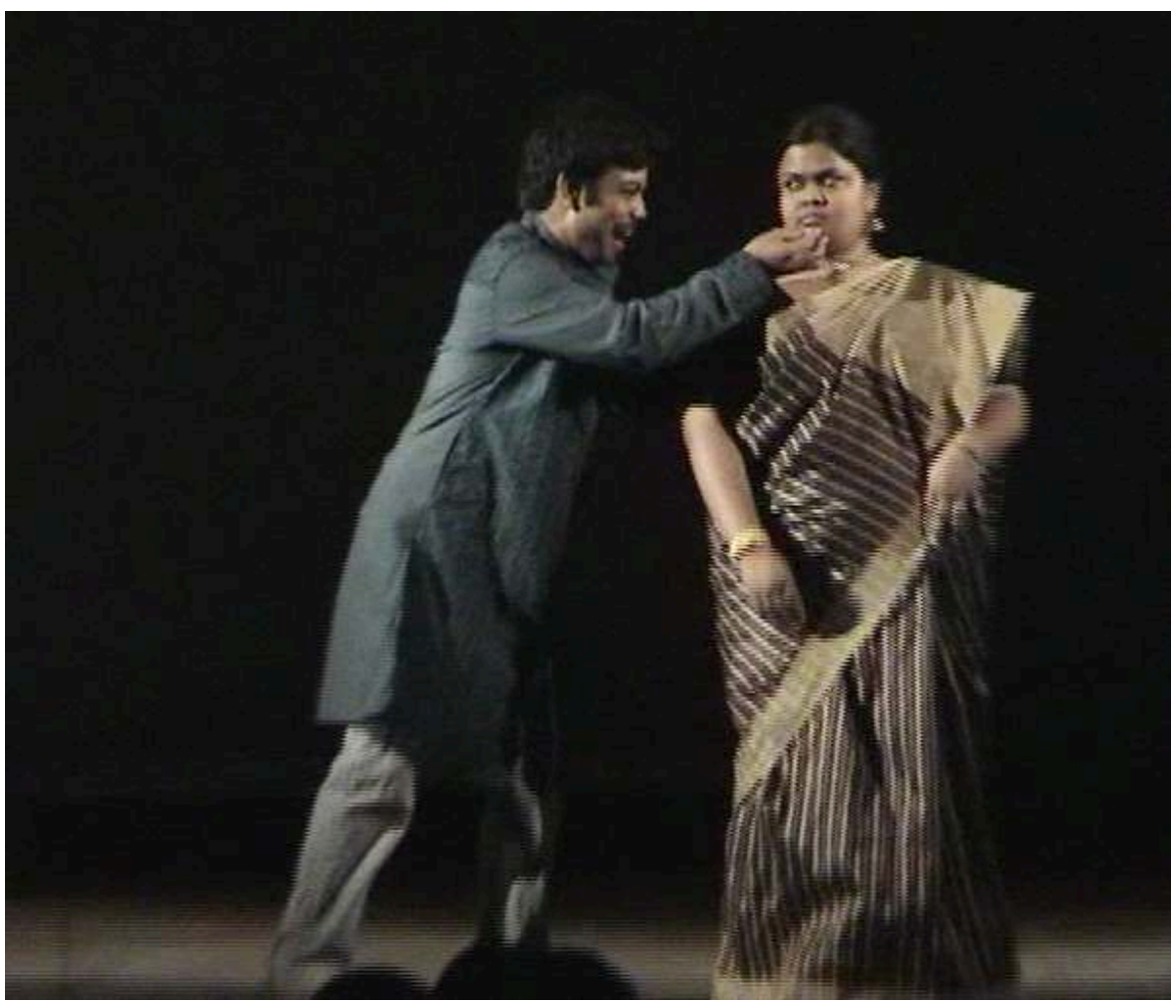

Figure 2: Macbeth (Animesh Biswas) attempts to placate his irate wife (Monikinkini Basu) by likening her to 'Munni' and 'Sheila' in scene II.

Radix 2012, Macbeth: A Comedy, 10 March 2012, screen grab (DVD).

STUDENTS OF THE ENgLISH DEPARTMENT, UNIVERSITY OF KALYANI (DVD 2012).

For an audience uninitiated to Indian films, the scene plays out a domestic tiff arising from Macbeth's infidelity (the witches and Hecate serve as his paramours in this tradaptation), where a philandering Macbeth desperately tries to placate his incensed spouse. Lady Macbeth proves extremely difficult to mollify until she is likened to "Munni" and "Sheila" - two very common names for Indian girls - in Macbeth's 
couplet, "Tui āmār Munni, tui āmār Sheila/ Tor sāthe korte pāri sārā sārārāt lilā" ["You are my Munni, you are my Sheila/ I could spend whole nights frolicking with you"]. For an Indian audience however, there is a huge difference between what they actually and virtually perceive, since the allusions provide a veritable orgy for voyeuristic male gaze through multiple spin-offs. "Munni" evokes the hugely popular song-and-dance routine, "Munni badnām hui" from the film Dabangg which not only has 'item specialist' Malaika Arora gyrating to heady music (Figure 3) but also invokes two other 'hot bods' of Bollywood with whom the dancer proudly equates herself by claiming, "Silpa jaisi figure aur Bebo si adaa" ["A figure like Shilpa and an attitude like Bebo"].

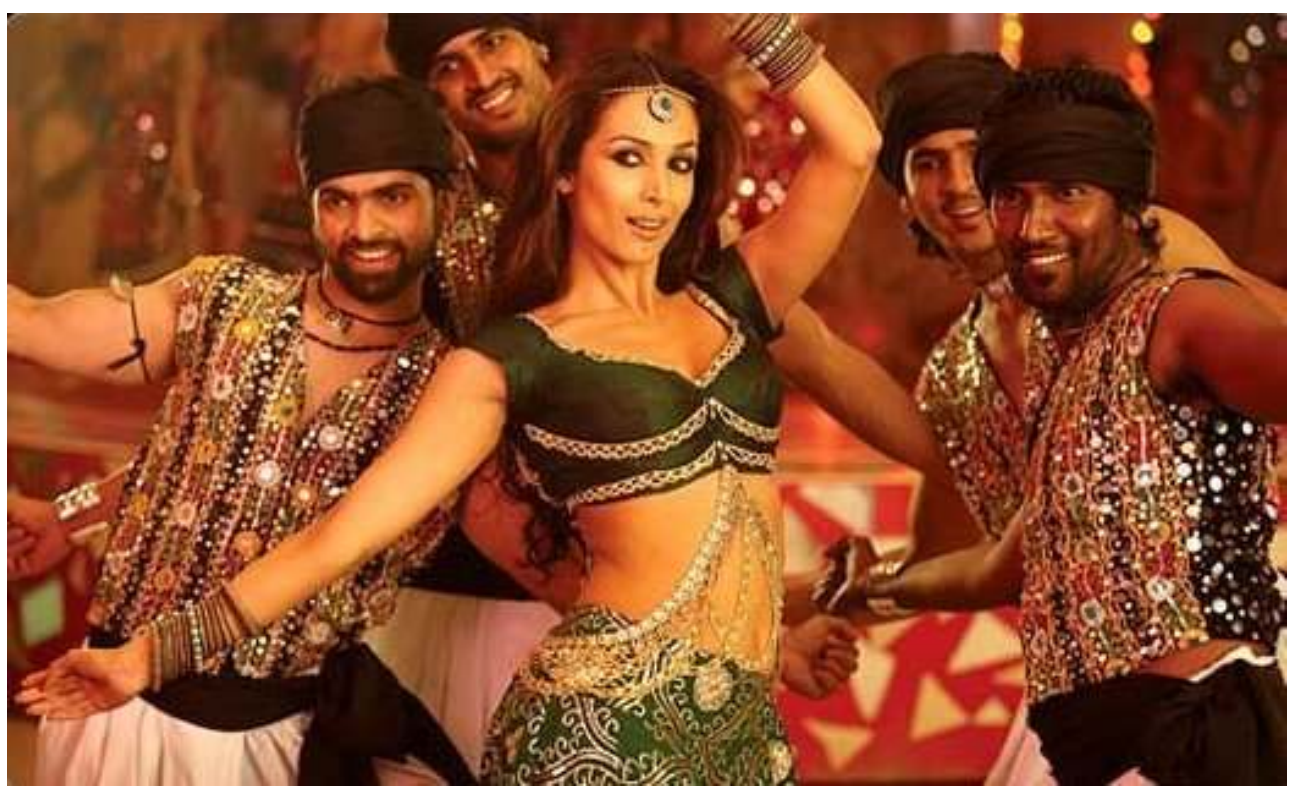

Figure 3: Malaika Arora in the item number "Munni badnām hui" from the Bollywood film Dabangg, directed by Abhinav Kashyap, produced by Arbaaz Khan Productions, 2010, screen grab (Youtube video).

URL: https://www.youtube.com/watch?v=Jn5hsfbhWx4, last accessed 9 August 2015.

Shilpa Shetty (Figure 4), admired largely for her alluring 'sex appeal', won the reality show Celebrity Big Brother Season 5 in 2007, broadcast on Channel 4 in the UK that earned her an audience with the British Queen ${ }^{16}$ and Bebo or Kareena Kapoor is reputed for flaunting her 'devil may care attitude' (Figure 5). 


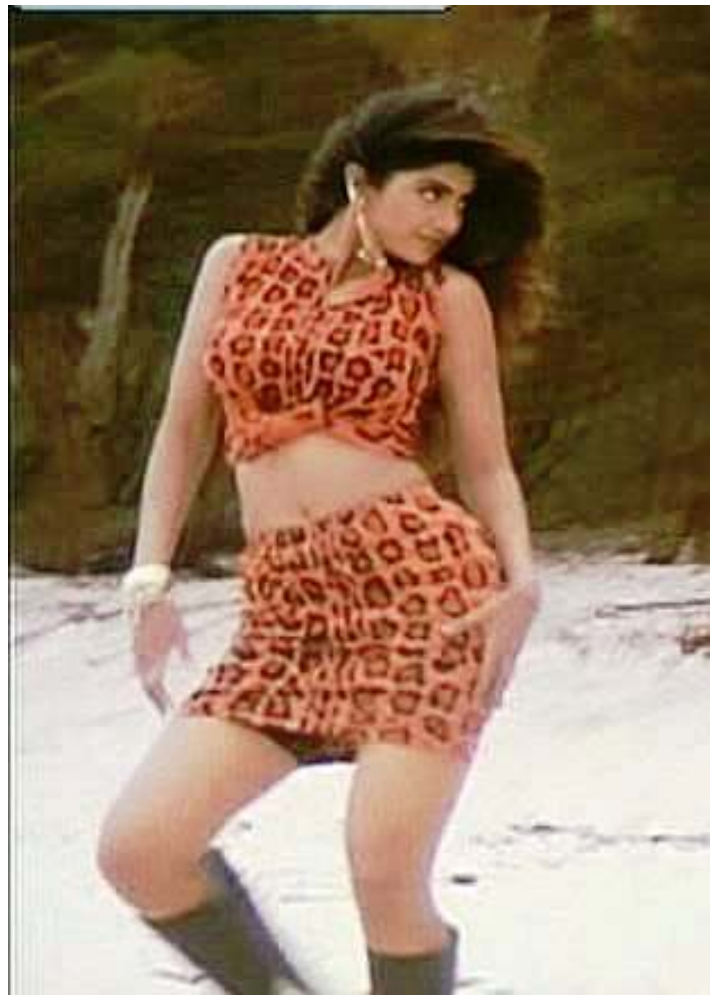

Figure 4: Bollywood actress Shilpa Shetty dancing to the tune of "Churake dil mera" ["Stealing my heart away"] in the film Main khiladi tu anari, directed by Sameer Malkan, produced by Champak Jain, 1994, screen grab (Youtube video).

URL: https://www.youtube.com/watch?v=-p1aKPmc7TQ, last accessed 22 August 2015.17

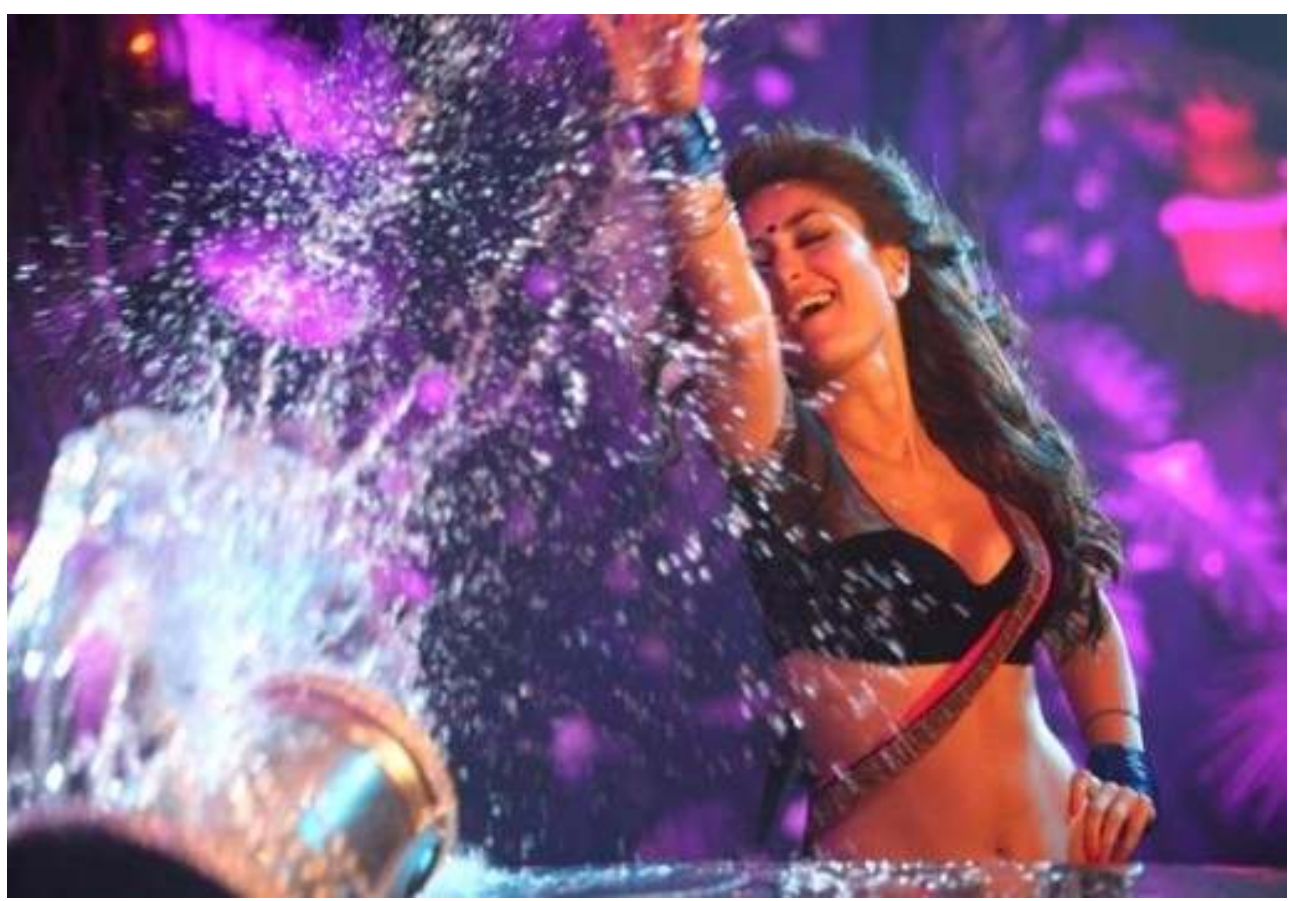


Figure 5. Kareena Kapoor in the item number "Halkat jawani" ["Spilling Youth"] from the film Heroine directed by Madhur Bhandarkar, produced by Ronnie Screwvala, Madhur Bhandarkar, Siddharth Roy Kapoor, 2012, screen grab (Youtube video).

URL: https://www.youtube.com/watch?v=1FJ9hTNLK4w, last accessed 23 August 2015. ${ }^{18}$

Similarly, "Sheila" stirs up steamy memories of Katrina Kaif, one of the highest paid 'heroines' of Bollywood, revelling in the inaccessibility of her well-exposed body with provocative movements in "Sheila ki jawāni" ["Sexy Sheila"] (Figure 6).

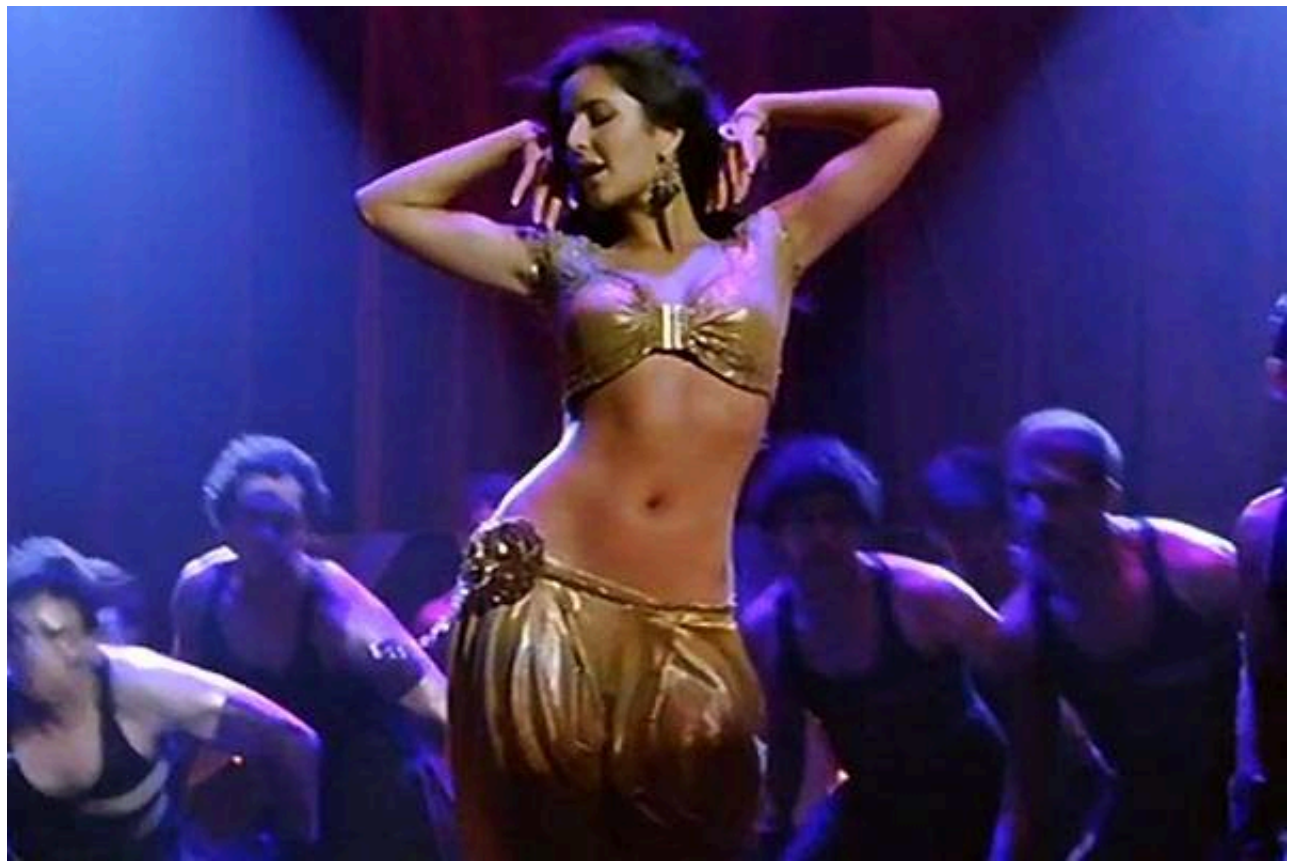

Figure 6. Katrina Kaif in the item number "Sheila ki jawāni" from the Bollywood film Tees mar khan directed by Farah Khan, produced by Twinkle Khanna, Shirish Kunder, Ronnie Screwvala, 2010, screen grab (Youtube video).

URL: https://www.youtube.com/watch?v=ZTmF2v59Ctl, last accessed 9 August 2015.

11 The dance rounds off with a visual 'quote' drawing attention to the self-referential selfreflexivity of film language. Katrina is lifted and carried above the heads of the male audience, holding cups in their hands, which is a throwback on a 1991 chartbuster item number "Jumma chumma" ["Double kiss"] featuring Kimi Katkar from the film, Hum (Figures 7 and 8). ${ }^{19}$ 


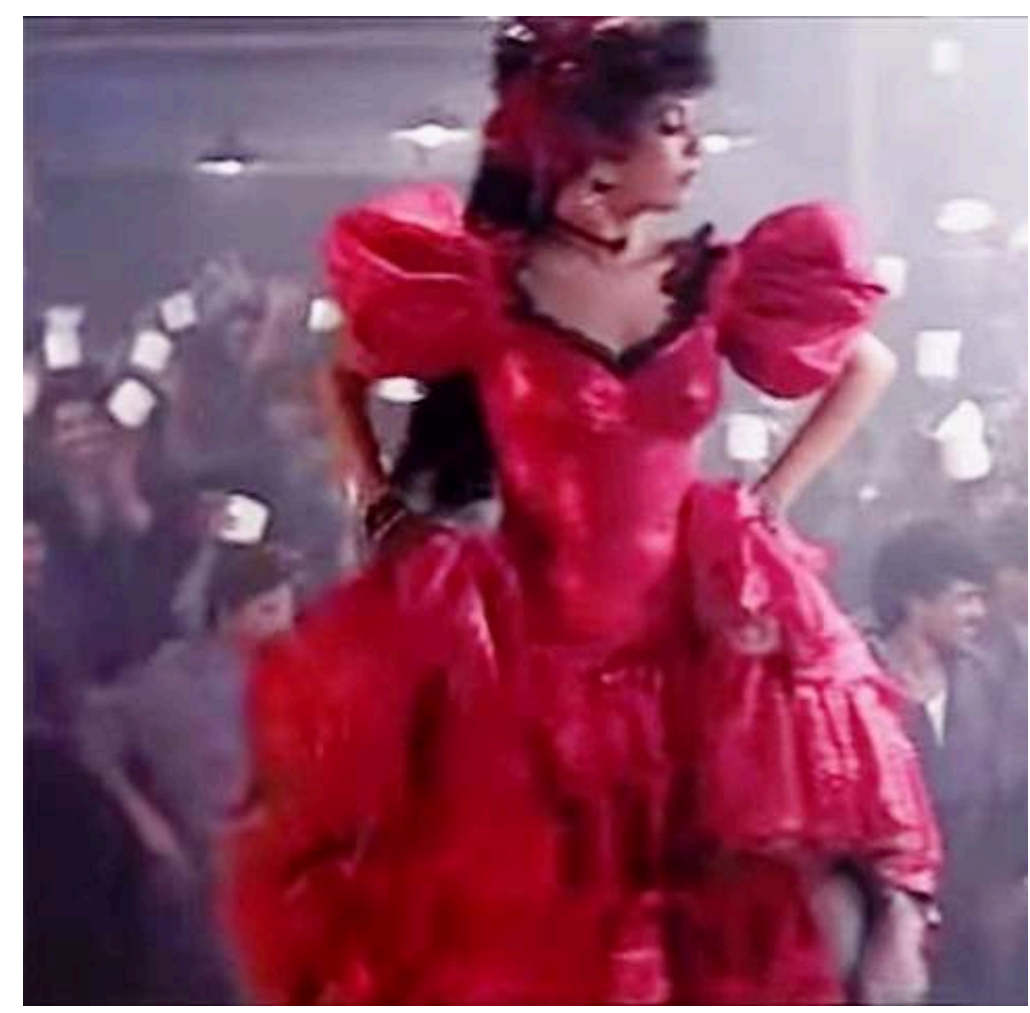

Figure 7: Kimmi Katkar in the hit item number "Jumma chumma" from Hum, directed by Mukul Anand and produced by Romesh Sharma, 1991, screen grab (Youtube video).

URL: https://www.youtube.com/watch?v=PSpot2bArRA, last accessed 14 August 2015.

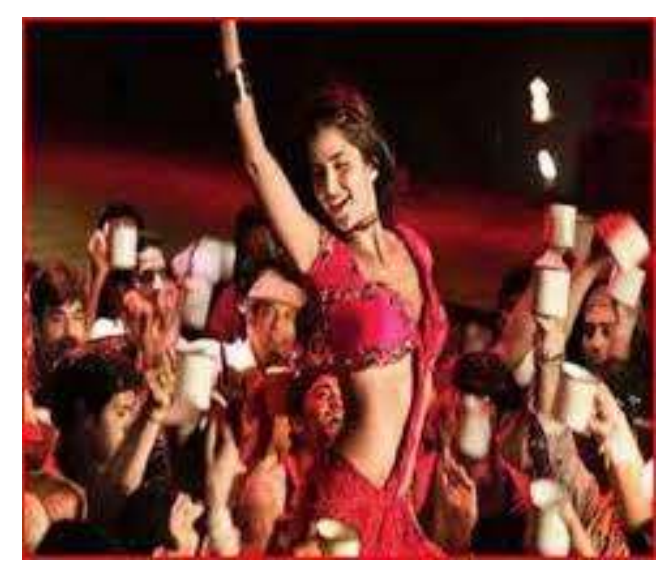

Figure 8: Visual 'quote' of the shot in "Sheila ki jawāni" with Katrina Kaif as the lead dancer in the film Tees mar khan, directed by Farah Khan and produced by Twinkle Khanna, Shirish Kunder, Ronnie Screwvala, 2010, screen grab (Youtube video).

URL: https://www.youtube.com/watch?v=ZTmF2v59Ctl, last accessed 9 August 2015.

However, it is the original couplet in the script, "Tui amar Munni, tui amar Sheila/ "Tui amar SCh, tui amar Nila" which truly opens up "th'access and passage" (1.5.42) to a precocious, transient, but for that very reason, deeply embedded associative recall accessible only to the chosen few. While a pan-Indian audience would instantaneously recall the alluring forms of Malaika and Katrina in "Munni badnām hui" and "Sheila ki jawāni" and, by implication, the 'come-hither' looks of Shilpa, Kareena and Kimmi, and 
revel in the ludicrousness of comparing them to the plump, stocky Lady Macbeth on stage, they would have no clue as to comic potential of acronyms like "SCh" and "Nila" for spawning a multilayered intertextuality. These allude to two senior female faculty members, one of whom teaches a large chunk of the Shakespeare course while the other is regarded as Miss 'prim and propah' with 'nary a hair or word ever out of place'. Visual images of (a) the middle aged teachers as Lady Macbeth (a plausible conjecture by the students especially during the time of examinations and results!), (b) the contrast between them and the Bollywood stars, (c) their ludicrous attempts at cavorting to the heady tunes, and the most audacious of all images, (d) the duo as paramours of Macbeth/ the student playing Macbeth, generated a pandemonium of subversive hilarity at every rehearsal. Unfortunately, both the student playing Macbeth and the tradapter developed cold feet during the rehearsals and resorted to impromptu replacement at the last moment although memories of the attempted transgression never failed to evoke suppressed laughter among the crew long after the performance. Thus, the local and ephemeral quality of the production, i.e., a one-time performance exclusively for the Departmental staff and students, past and present, paradoxically enriches the production through its closed circuit of references, reminiscences and experiences accessible to an in-house audience. This contingent self-referential ephemeral quality of the production also undercuts what Bulman terms as "textual monumentality" - the iteration of Shakespeare's authority through repeated performance which "encourages us to assimilate that performance to the condition of a literary text" as "a stable artefact." 20

\section{Performance}

The consistent deployment of confrontational bilingualism is augmented by theatrical juxtaposition that fragments the act of "seamless transmission" and challenges Pratt's "contact zone" proposition by upholding rather than dissolving the binary between auditory and visual transmission..$^{21}$ The play opens aptly, for instance, with the famous "Fair is foul" lines (1.1.10-11) but the sexually indeterminate and repulsive witches are replaced by comely maidens of Kalyani variety cavorting to a mix of African drum beats and Native American music (Figure 9). ${ }^{22}$ 


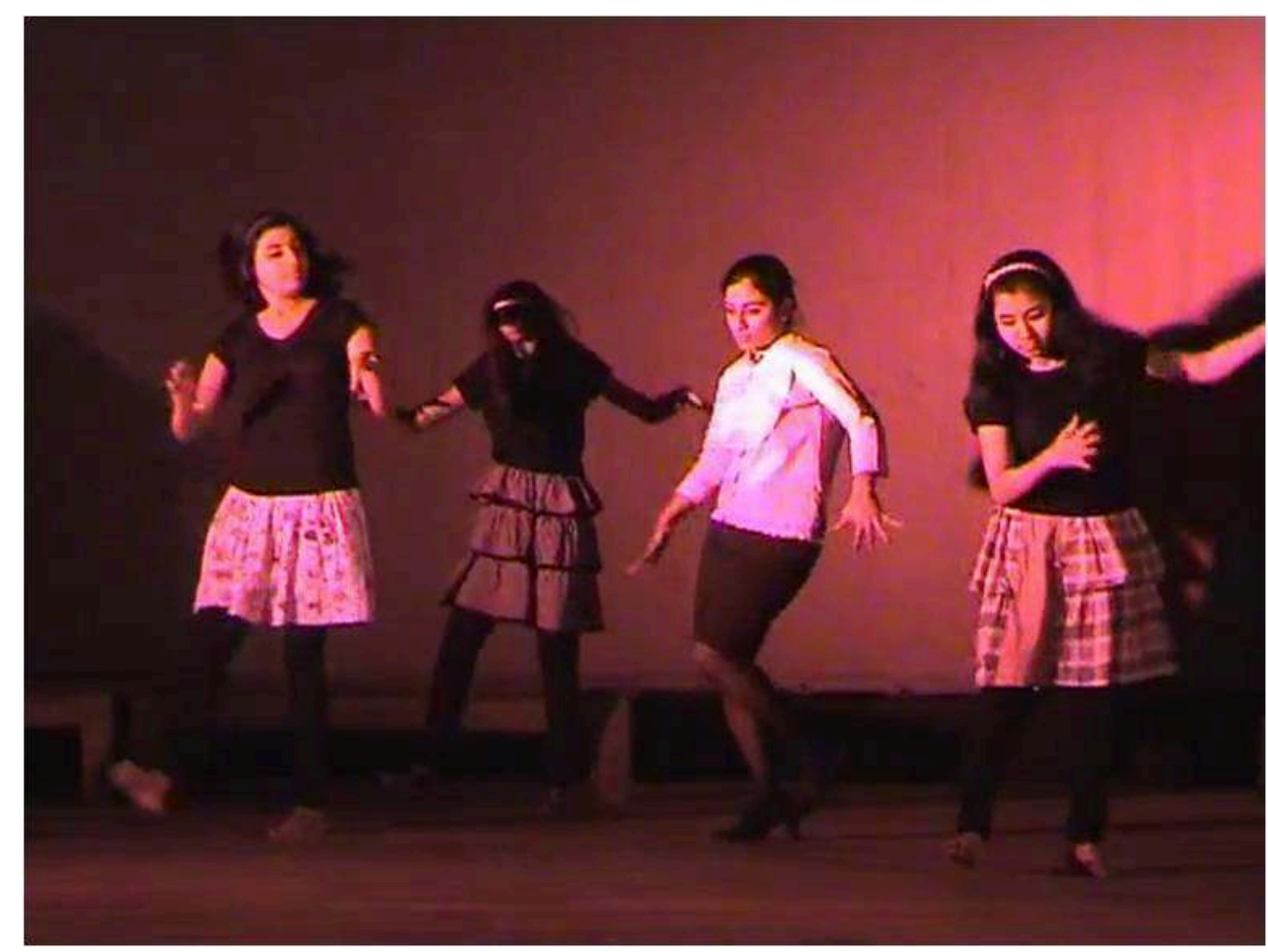

Figure 9: Radix's reworking of the cauldron scene (3.5) where Hecate (Sayantani Halder) and the witches (clockwise: Keya Barai, Sneha Bannerjee, Moumita Ghosh,) enter dancing to the music of the "Drums of Defi" in scene V.

Radix 2012, Macbeth: A Comedy, 10 March 2012, screen grab (DVD).

STUDENTS OF THE ENgLISH DEPARTMENT, UNIVERSITY OF KALYANI (DVD 2012).

14 As the kurta-pajama clad Macbeth and Banquo notice them for the first time, a deliberate contrast between the verbal signifier and the visual signified forces an either/ or choice upon the audience: they can either subscribe to the veracity of the original lines - "What are these,/ So wither'd and so wild in their attire,/ That look not like th'inhabitants o'the earth" (1.3.37-39) - and reconfigure the leotard and skirt clad postgraduate female students as "wither'd" and "wild" in their imagination or, acknowledge the inadequacy of Shakespeare's description. One is reminded of a similar challenge to audience susceptibility in Trevor Nunn's close up shot of Imogen Stubbs's Viola facing Steven Mackintosh's Sebastian (Figure 10), lasting exactly sixteen seconds, which exhorts a leap of blind faith to accept the two as identical twins. 


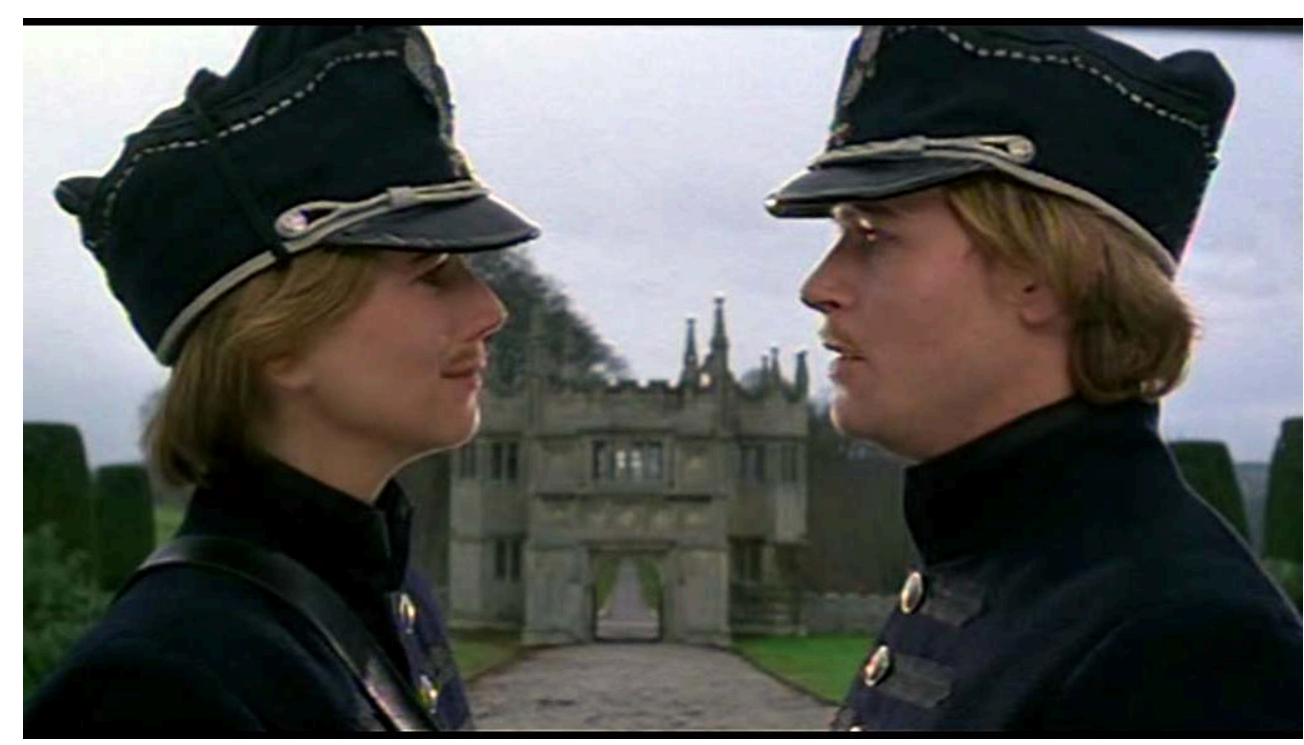

Figure 10: Viola (Imogen Stubbs) and Sebastian (Steven Mackintosh) are reunited in a shot that lasts sixteen seconds in Twelfth Night directed by Trevor Nunn, produced by Newmarket Capital Group LP, Summit Entertainment N.Y. \& BBC Films, 1996, screen grab (Youtube video).

URL: https://www.youtube.com/watch?v=S69vCzMRAi0, last accessed 7 April 2015.

The ensuing clash between our visual and auditory experiences in both the productions creates a V-effect that challenges the very notion of theatrical mimesis as sustained and credible. In the Radix production, however, the Brechtian alienation is unfairly loaded against the author since the divide between the spectators and actors is highly temporary and illusory: all are classmates and well aware of the fact that two of the witches (Sneha Bannerjee and Moumita Ghosh) are real life 'girlfriends' of on-stage Macbeth (Animesh Biswas) and Banquo (Saugata Chakraborty) respectively and the irony of having to describe their own lady loves as old and decrepit adds considerably to the mirth.

Bassnett and Trivedi's definition of translation as "a highly manipulative activity" ${ }^{23}$ is exemplified by the myriad variety of locational, situational and stylistic transpositions that severely undermine the tragic ambience of Macbeth. Lady Macbeth's exit lines in the 'sleep walking scene', "Come, come, come, come, give me your hand. What's done cannot be undone. To bed, to bed, to bed" (5.1.57-58) are repeated verbatim by Macbeth who enters immediately after, to Sneha, one of the three witches (and his real-life girlfriend) who demurs coquettishly, "No, no, no, not to bed now" (scene V). Frequent recourse to such metatheatricality throughout the performance succeeds precisely because of the closed nature of the production: a miniscule community of spectators and actors which has shared access to the text as well as to the various subtexts that facilitate informed and additional gratification.

Spoof acting of serious scenes generate similar merriment. In scene II, Lady Macbeth enters reading Macbeth's missive informing her of his encounter with the witches (1.5.1-12). In the Shakespearean tragedy, this letter and the news of Duncan's imminent visit to Inverness leads to one of the most chilling utterances in the play "Unsex me here" (1.5.38-52). In Macbeth: A Comedy, the passage from the letter to the invocation of the spirits is drastically abridged, moving rapidly from the opening lines of Macbeth's communication (1.5.1-3) to "Hie thee hither [...] valour of my tongue" (1.5.23-25) and 
then directly to "Come, you spirits. [...] Th'effect and it" (1.5.38-45). The retained lines however, are Shakespeare verbatim. Yet the intensity of high tragedy is displaced by double edged mirth through the visual dissipation of horror into comedy premised upon unsuitable acting and the trivialization of the content by re-contextualising it in terms of adulterous desire, not political ambition. Already annoyed by Macbeth's waywardness, Lady Macbeth is charged by the phrase "burned in desire" (1.5.3) in his letter; with blazing eyes, rotating shanks, pointed finger and vixen-like shrillness, she demands to be unsexed so that she may "chastise" unfaithful Macbeth with the "valour" (1.5.25) of her tongue and inflict "direst cruelty" (1.5.40) on him. Full credit goes to actor Monikinkini Basu who makes a virtue out of forgetfulness and cuts short the rest of the missive included in the script, seizing upon the mention of "desire" - which she repeats for emphasis - to embark upon the invocation to spirits with hilarious results (Figure 11).

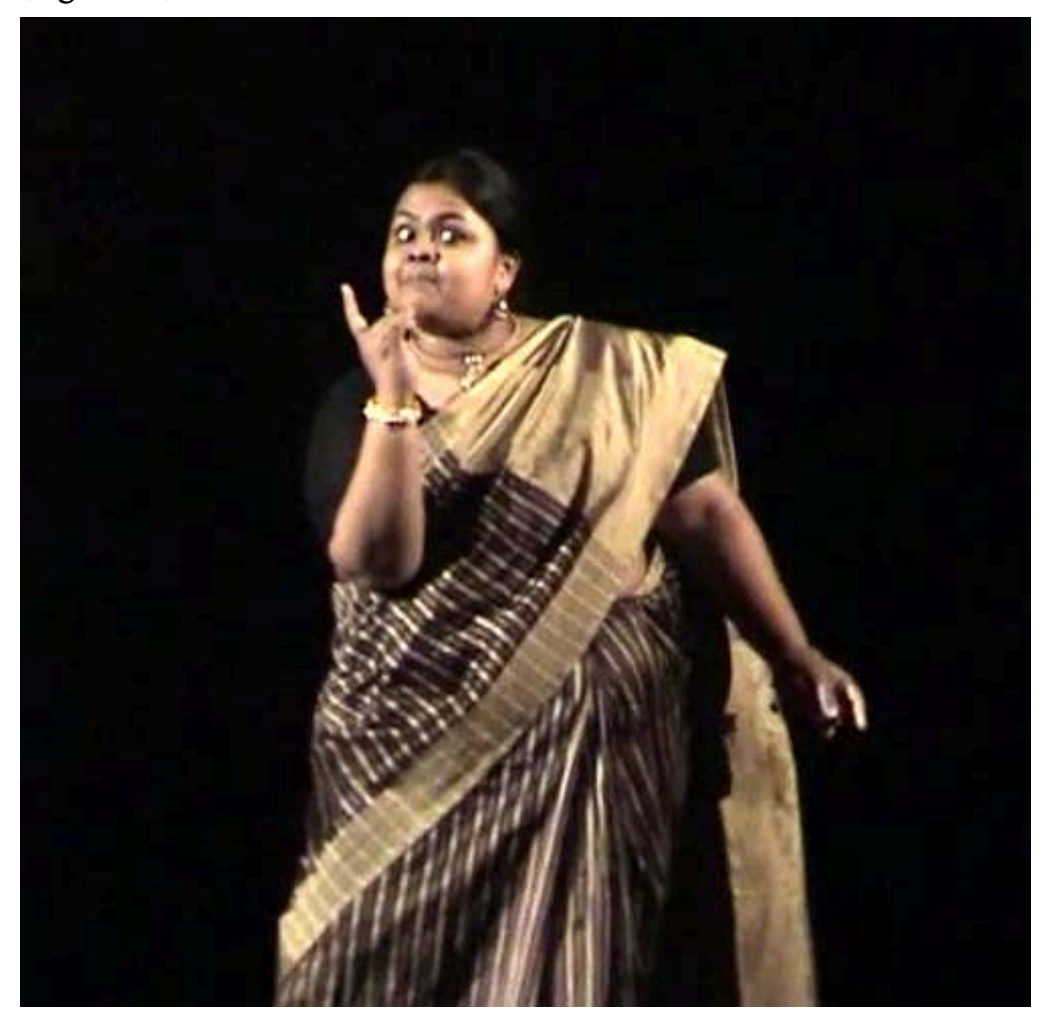

Figure 11: Lady Macbeth (Monikinkini Basu) invoking the spirits to unsex her so that she can teach a lesson to philandering Macbeth in scene II.

Radix 2012, Macbeth: A Comedy, 10 March 2012, screen grab (DVD).

STUDENTS OF THE ENgLISH DEPARTMENT, UNIVERSITY OF KALYANI (DVD 2012).

Anthony B. Dawson, discussing performance strategies and the function of the actor's body suggests the "personation process" as an essential prerequisite for successful role play: "in order to make the audience recognize and respond to what the impersonated person feels" the actor must ensure the "elision of [his own] body," simultaneously "mounting it as a scaffold" to transmit the text and the character. ${ }^{24}$ According to him, the central paradox of the theatre is that "the truthful body always lies" 25 - the personated body is a fiction made real by the elision of the actor's body. The scene discussed above requires an even more complex use of the body on the stage since it is concurrently enacting two scripts: Monikinkini's emotive enunciation and intonation 
replicate the terrifying de-naturalised protagonist of the tragedy proper while her facial expressions and body language iterate the comic stereotype of the shrew. Contrary to the Dawsonian theory of "transferral" 26 as a composite interiorisation of the personated character, the scene succeeds through a split, binary mode of self-reflexive representation. Monikinkini's articulation and gestures are deliberately at cross purposes with each other juxtaposing, rather than amalgamating, the two Lady Macbeths and drawing the audience's attention to the intransigent, overweight, body of the actor which does not lie.

The continuous discontinuity of sporadic translations, extralingual interventions, aggressive dislocations redefine the relationship between the source text and the target text which is explicated by the choric deployment of the Porter (2.3) at the close of the play (scene VI). The stock device of the freeze is used in this concluding scene to separate the Porter from the rest of the cast who have all descended to Hell, including Duncan (who appears for the first time in the play) and the witches. As the aggrieved victims of Macbeth - Duncan, Banquo and Lady Macbeth (suffering subjects/ students?) - maul Macbeth (Shakespeare/ English Studies?) on rear stage with Hecate and her brood as amused onlookers (Radix audience?) (Figure 12), the Porter traverses the front stage speaking directly to the audience.

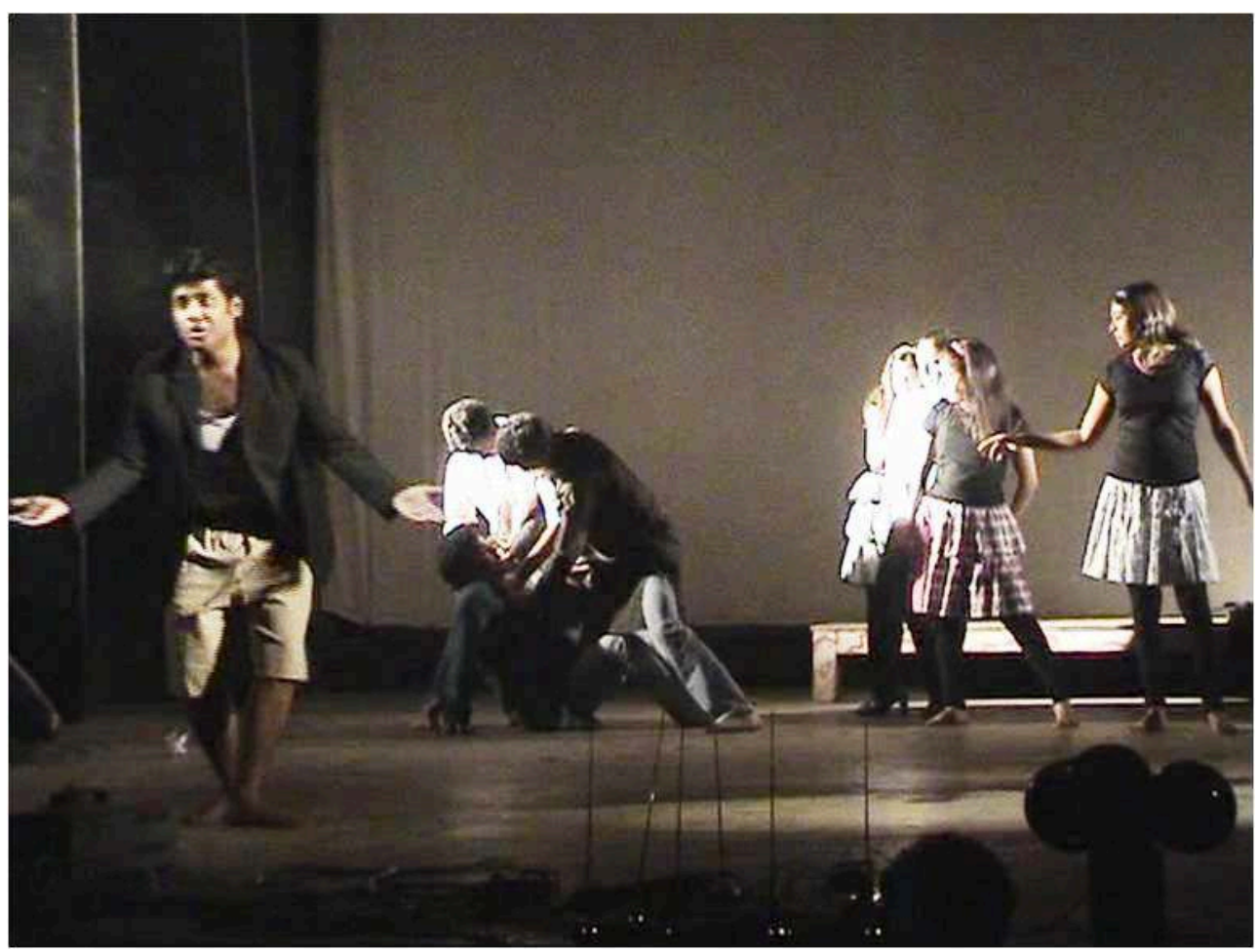

Figure 12: Hell Porter (Debayan Banerjee) delivers the 'Epilogue' while, in the freeze backstage, Duncan (Sumanta Chakraborty) and Banquo (Saugata Chakraborty) beat up Macbeth (Animesh Biswas) in the presence of the witches (Sneha Bannerjee, Moumita Ghosh, Keya Barai) just before the entry of Lady Macbeth in scene VI.

Radix 2012, Macbeth: A Comedy, 10 March 2012, screen grab (DVD).

STUDENTS OF THE ENgLISH DEPARTMENT, UNIVERSITY OF KALYANI (DVD 2012).

This creates two distinct zones: one at the back and another stretching from the front stage to the auditorium, distancing the audience from the 'play proper' to facilitate 'critical viewing' and simultaneously enabling them to cross over and occupy the stage 
by establishing a close rapport between the chorus and the audience. Both are situated, in terms of perspective, above the play as they, together, attempt to comprehend the rationale, or rather, the illogicality of the show.

In Shakespeare and the Problem of Adaptation, Margaret Jane Kidnie describes adaptation as "the addition of new material alongside substantial cutting and rearrangement" and transformation as "the most extreme mode of innovation" where characters are "simplified or trundled through new events." ${ }^{27}$ Such practices are instanced to some extent in the production but it also travesties these transference strategies with impunity as the Porter issues repeated reminders of changing times, space, customs and perception and bandies about concepts of transculturation, mimicry, new historicism, cultural materialism, parody, challenging the audience to make sense of this "post-modern riddle" (scene VI). Sample, for instance, the following excerpts from the Porter's speech:

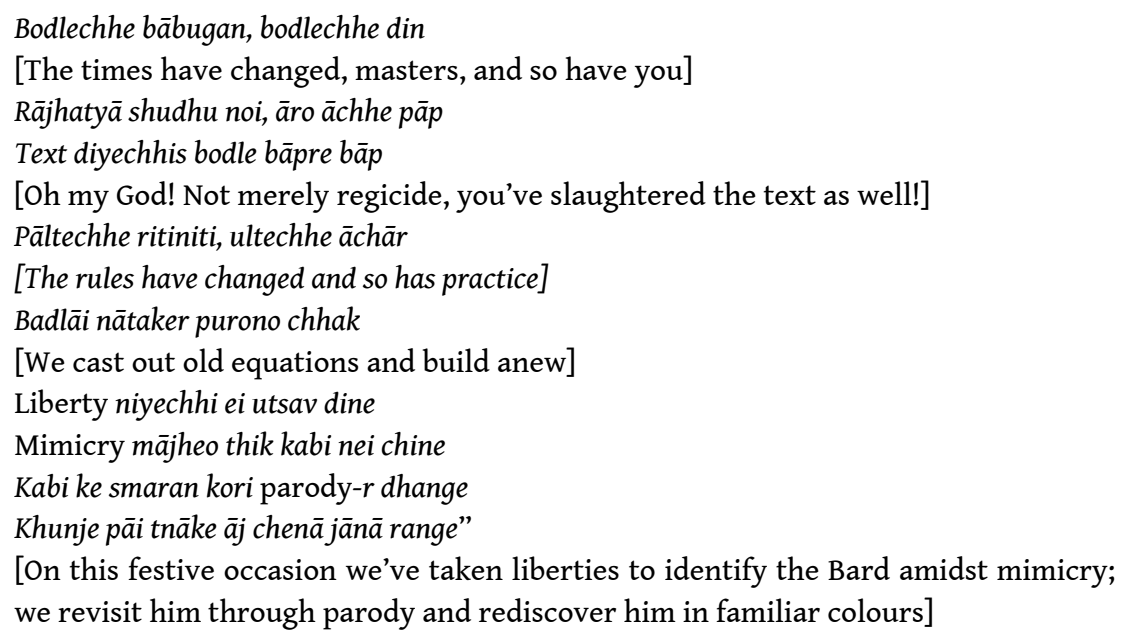

This unabashed celebration of "prolific unauthenticity" ${ }^{28}$ suggests mockery as the primary means of accessing Shakespeare in a twenty-first century suburban higher education scenario of Bengal: "Knock, knock, knock, knock/ Sabbai mile kori Shakespeare mock" ["Knock, knock, knock, knock/ All together, we Shakespeare mock" (scene VI)]. It entails the simultaneous estrangement of the text from its author and milieu and its subordination to non-European indigenous environs.

One might be tempted to regard Macbeth: A Comedy as a presentist enterprise since it does "talk to the living" rather than "speak with the dead" which, according to its formulators Hugh Grady and Terence Hawkes, is a major thrust of presentism. ${ }^{29}$ But instead of investigating how the Shakespearean tragedy engages with present reality, and becomes in the process, "our universally adaptable contemporary," ${ }^{30}$ this Departmental production interpellates Shakespeare in local space and time and interrogates the "substance of [his] tragedy" (emphasis added) by exposing its unsuitability (in the original form) in the context of contemporary reality and purpose. It posits a new kind of post-postcolonial hybridity that neither attempts to "terrorize [...] authority with the ruse of recognition" nor "reimplicate [...] its identifications in strategies of subversion that turn the gaze of the discriminated back upon the eye of power." 32 Instead, it seems "more concerned with attracting the gaze of the discriminated with the otherness of its own composition, redirecting its gaze to its own cultural genealogy" (emphasis added). ${ }^{33}$ Rejecting the "in-betweenness" of "Third Space" ${ }^{34}$ in favour of reclaiming the centre, the project of displacing the tragedy of ambition with a 
rumbustious comedy of lust generates in its wake our very own Shakespeare full of fun and frolic.

\section{NOTES}

1. An early draft of this paper was presented at the Shakespeare 450 International Conference organised by The Société française Shakespeare from 21 to 27 April 2014 in Panel 7, "Telling Tales of/ from Shakespeare: Indian Ishtyle," convened by P. Trivedi and S. Chaudhury. I am indebted to Poonam Trivedi, Paromita Chakraborty, Thea Buckley, Swati Ganguly and Arpita Ghosh for their comments on the draft. "Ishtyle" is the colloquial version of 'style' in Bengali and Hindi with a dig at the general Indian tendency of adding an ' $i$ ' before pronouncing ' $s$ ' when immediately preceding a consonant; 'smile' for instance may often be pronounced as 'ismile.' For a more detailed discussion of Indian Shakespearean negotiations, specially with reference to Bengal's engagement with Macbeth, see Sarbani Chaudhury and Bhaskar Sengupta, "Macbeth in Nineteenth-Century Bengal: A Case of Conflicted Indigenization", Multicultural Shakespeare: Translation, Appropriation and Performance, 10 (2013): 6-18 (DOI: 10.2478/mstap-2013-0002. July 2013).

2. Indian pop music.

3. Bollywood/ Hollywood. "Bollywood," an obvious take-off on "Hollywood," refers to the thriving Hindi film industry located in Bombay, a town which has now been rechristened Mumbai.

4. Nobel Laureate Rabindranath Tagore (1861-1941), reformer, thinker and the author of plays, songs, novels, short stories, essays - the most iconic figure of Bengali culture. In Bengal, both Rabindranath Tagore and Shakespeare are frequently referred to as 'kabiguru' [poet sage]. In fact a common wordplay on 'Shakespeare' in Bengali is 'Saksyapeer' [friendly sage].

5. Dir.: Radix 2012; Producers: Students of the English Department, University of Kalyani; Trans. adapt. \& stage: Sandip Mandal; Music: Sandip Mandal, Marina Chatterjee; Choreography: Debashish Acharya; Costume: Sarbani Chaudhury; Cast: Animesh Biswas (Macbeth), Manikinkini Basu (Lady Macbeth), Saugata Chakraborty (Banquo), Sneha Bannerjee, Moumita Ghosh, Keya Barai (Witches), Sayantani Halder (Hecate), Debayan Banerjee (Porter), Sumantra Chakraborty (Duncan).

6. All citations from the Macbeth are from John Jowett, William Montgomery, Stanley Wells and Gary Taylor eds., Shakespeare's Plays: The Complete Works, $2^{\text {nd }}$ edition, Oxford, Oxford University Press, 2005.

7. All citations from the Radix version of Macbeth are from Sandip Mandal, Macbeth: A Comedy, 2012, n. pag., mss. All translations of passages cited from this text are mine.

8. Shakespeare was the mainstay of the English syllabus officially introduced in India to create, as Thomas Babington Macaulay amplifies in his Minute on Education (1835), bipolar subjects "Indian in blood and colour, but English in taste, in opinions, in morals" (accessible online at: http:// home.iitk.ac.in/ hcverma/Article/Macaulay-Minutes.pdf, last accessed 5 September 2015). Consequently, the hierarchic relation between Shakespeare (source text) and his Indian translation (target text) was a foregone conclusion in the colonial era and persists till today. Against this backdrop, the counter-trend highlighted by the Radix production acquires special significance. 
9. The included scenes are dispersed in the six scenes of the performance text in the following manner: scene I - 1.3.1-40, 46, 55-59; scene II - 1.5.1-12, 23-25, 38-46; 1.7.31, 35-36, 59-61; 2.2.8-10, 12-14; 2.3.70-71, 83; scene III - nil; scene IV - 3.4. 49-50, 70-72; scene V - 5.1.30-31, 33-34, 42-43, 56-58; 5.5.7-8, 16-20; scene VI - 2.3.3.

10. David V. Mason, "Who is the Indian Shakespeare? Appropriation of Authority in a Sanskrit Midsummer Night's Dream”, New Literary History 34.4, Autumn 2003, 639-658, p. 642.

11. Tejaswini Niranjana, "Translation, Colonialism and the Rise of English", in Svati Joshi ed., Rethinking English: Essays in Literature, Language and History, Delhi, Oxford University Press, 1994, p. 161-177, p. 162.

12. Item numbers are 'stand alone' formulaic dance sequences in mainstream Hindi films that have little or no connection with the narrative and are inserted primarily for voyeuristic titillation.

13. All translations from Hindi and Bengali into English, unless otherwise stated, are mine.

14. "Munni badnām hui" (https://www.youtube.com/watch?v=Jn5hsfbhWx4, last accessed 9 August 2015) and "Sheila ki jawāni" (https://www.youtube.com/watch?v=ZTmF2v59CtI, last accessed 9 August 2015) are chartbuster item numbers from the 2010 film releases Dabangg and Tees mar khan featuring Malaika Arora and Katrina Kaif respectively.

Dabangg (2010), Dir.: Abhinav Kashyap; Production: Arbaaz Khan Productions; Music: Sajid-Wajid and Lalit Pandit. Malaika Arora Khan appears only in the item number, "Munni badnaam hui" inspired by an old Bhojpuri folk song, sung by Mamta Sharma and Aishwarya Nigam and choreographed by Ganesh Acharya (for further information on cast and credits see: http:// www.imdb.com/title/tt1620719/fullcredits/, last accessed 9 August 2015).

Tees maar khan (2010), Dir.: Farah Khan; Production: Twinkle Khanna, Shirish Kunder, Ronnie Screwvala; Music: Vishal-Shekhar and Shirish Kunder. Although the response to the film was lukewarm, "Sheila ki jawāni," penned by Vishal Dadlani, sung by Sunidhi Chauhan and choreographed by Farah Khan became the rage and won several awards (for further information on cast and credits see: http://www.imdb.com/title/tt1572311/fullcredits?ref_=tt_ov_st_sm, last accessed 9 August 2015).

15. The song (https://www.youtube.com/watch?v=vM9jszm63RM, last accessed 9 August 2015) is from the blockbuster Rajkumar (1964), Dir.: K. Sankar; Producer: G. N. Velumani; Music: ShankarJaikishan; Lyrics: Hasrat; Singer: Lata Mangeshkar (accessible online at: http://filmkahani.com/ bollywood-old-songs-lyrics/rajkumar-aa-ja-aai-bahar-dil-hai-bekrar-lyrics.html, last accessed 4 April 2015).

16. The show, hosted by Davina McCall, ran for 26 days, from 3 to 28 January 2007, and was also broadcast on channel S4C in Wales. On 28 January 2007, Shetty was voted the winner of Celebrity Big Brother 5 with $63 \%$ of the final vote. The show earned notoriety because of the racist bullying of Shilpa Shetty by other housemates Jade Goody, Danielle Lloyd and Jo O'Meara which sparked widespread anger and demonstrations in India and led Big Brother's main sponsor Carphone Warehouse to suspend its sponsorship of the show. It also facilitated Shilpa Shetty's meeting with Queen Elizabeth II which took place at Marlborough House in London in March 2007 (for more on this topic see: http://en.wikipedia.org/wiki/Celebrity_Big_Brother_5, last accessed 19 March 2014).

17. Main khiladi tu anari (1994), Dir.: Sameer Malkan; Production: Champak Jain; Music: Anu Malik. The song, "Churake dil mera" sung by Alka Yagnik and Kumar Sanu, penned by Rahat Indori, and choreographed by Saroj Khan/ Chinni Prakash became quite popular (accessible online at: http://www.glamsham.com/music/lyrics/main-khiladi-tu-anari/chura-ke-dil-mera/

147/6469.htm, last accessed 23 August 2015; for further information on cast and credits, see http://www.imdb.com/title/tt0110438/fullcredits?ref_=tt_ov_st_sm, last accessed 23 August 2015). 
18. Heroine (2012), Dir.: Madhur Bhandarkar; Production: Ronnie Screwvala, Madhur Bhandarkar, Siddharth Roy Kapoor; Music: Salim-Sulaiman. The film was panned by the critics but the item number "Halkat jawani" sung by Sunidhi Chauhan, penned by Niranjan Iyengar and choreographed by Ganesh Acharya went on to become a chartbuster (accessible online at: http:// hindigeetmala.net/song/halkat_jawani_life_ki_notty_kahani.htm, last accessed 23 August 2015). 19. Hum (1991), Dir.: Mukul S. Anand; Production: Romesh Sharma; Music: Laxmikant-Pyarelal; The song "Jumma Chumma" penned by Anand Bakshi was sung by Sudesh Bhonsle and Kavita Krishnamurthy and the dance was choreographed by Chinni Prakash (accessible online at: http://www.lyricsoff.com/songs/jumma-chumma-de-de.html, last accessed 9 August 2015).

20. James C. Bulman, "Introduction: Shakespeare and performance theory", in Bulman ed. Shakespeare, Theory, and Performance, London \& New York, Routledge, 1996; Taylor \& Francis eLibrary, 2005, p. 1-11, p. 2.

21. Mary Louise Pratt, Imperial Eyes: Travel Writing and Transculturation, London \& New York, Routledge, 1992, p. 6-7.

22. Scene I: Drums of Thunder (Native American Music) "Mountain Spirits" (accessible online at: http://clip.dj/drums-of-thunder-native-american-music-mountain-spirits-download-mp3-mp4DYvNAHByKPM\#v/HcRyroppRCU, last accessed 24 March 2014); Scene V: African Tribal Music "Drums of Defi" (accessible online at: http://blip.fm/listen/African+Tribal+Music::Drums+of+Defi, last accessed 24 March 2014).

23. Susan Bassnett and Harish Trivedi, "Introduction: Of colonies, cannibals and vernaculars", in Susan Bassnett and Harish Trivedi eds., Post-colonial Translation: Theory and Practice, London, Routledge, 1999, p.1-18, p. 2.

24. Anthony B. Dawson, "Performance and Participation: Desdemona, Foucault, and the Actor's Body", in James C. Bulman ed., Shakespeare, Theory, and Performance, London \& New York, Routledge, 1996; Taylor \& Francis e-Library, 2005, p. 31-47, p. 35, 38.

25. Ibid., p. 38.

26. Ibid.

27. Margaret Jane Kidnie, Shakespeare and the Problem of Adaptation, London, Routledge, 2009, p. 16.

28. Gayatri Chakravorty Spivack and Sneja Gunew, "Questions of Multiculturalism," in Simon During ed., The Cultural Studies Reader, London, Routledge, 1993, p. 183-202, p.183.

29. Hugh Grady and Terence Hawkes, eds., Presentist Shakespeares, Abingdon, Routledge, 2007, p. 4.

30. Kornelia Taborska, "Shakespeare Colonized: The Māori Merchant of Venice and the Question of Exclusion," a paper presented at the "XI Conference of the European Society for the Study of English" held at Bogazici University, Instanbul, 4 to 8 September 2012, in Seminar 72, "Have We Devils Here?" Exclusion in Shakespeare Studies, mss., p. 1.

31. Bradley, op. cit., p. 1-29.

32. Homi Bhaba, "Signs Taken for Wonders: Questions of Ambivalence and Authority under a Tree outside Delhi, May 1817”, Critical Inquiry 12, 1985, 144-165, p. 157, 154.

33. Mason, op. cit., p. 653.

34. Homi Bhaba, The Location of Culture, London \& New York, Routledge, 1994, p. 38-39. 


\section{ABSTRACTS}

Radix, the annual reunion of the Department of English, University of Kalyani, regularly showcases the insidious seepage of high voltage Indi-pop, Bolly/ Holly dance numbers, into the culturally admissible recitals of classical dance, music, and Tagore songs. From 2008 to 2012, the highpoint of the day's festivities has been the staging of a raunchy, risque and impudently abridged version of a Shakespearean play. This article investigates the tenor of the last production, the 'comedy' of Macbeth, which cannibalizes, digests and regurgitates a diametrically split Shakespeare for local consumption. The complete collectivization of the page-to-stage process, the consistent deployment of confrontational trilingualism (Bengali, Hindi and English) and the foregrounding of the binary relationship between the source and the target text fragment the act of "seamless transmission," challenging Pratt's "contact zone" formulation regarding the act of translation. Together, these features move beyond the postcolonial desire to write/ right back, rejecting the "in-betweenness" of Homi Bhaba's "Third Space" in favour of reclaiming the centre and creating, in the process, our very own Shakespeare full of fun and frolic.

Le congrès annuel du Département d'Anglais de l'Université de Kalyani ("Radix ») est l'occasion de voir régulièrement la musique Indi-pop sur-vitaminée et les numéros de danse à la «Bollywood" ou "Hollywood» se mêler aux représentations culturellement acceptables (récitals de danse et de musique classique, chansons de Tagore). De 2008 à 2012, le point d'orgue des festivités fut la représentation d'une version abrégée d'une pièce de Shakespeare, marquée par son caractère lascif et osé. Cet article s'intéresse à la dernière représentation, la " comédie » Macbeth, qui ingère, digère et recrache un Shakespeare divisé, adapté à la consommation locale. Cette entreprise collective de transformation, dans laquelle se déploie un trilinguisme agressif (bengali, hindi et anglais) et qui met au premier plan la relation binaire entre texte source et texte cible, fragmente l'acte de transmission homogène et remet ainsi en cause la «zone de contact " postulée par Pratt dans l'acte de traduction. L'expérience dépasse le désir postcolonial de « répondre » («to write/ right back») et rejette «l'entre-deux » du "tiers-espace » d'Homi Bhabha afin de permettre une réappropriation du centre et la création d'un Shakespeare propre à l'Inde, léger et amusant.

\section{INDEX}

Mots-clés: autorité, collaboration, genre, Macbeth, mise-en-scène, multilinguisme, Shakespeare en Inde, théâtre éphémère, tradaptation

Keywords: binary acting, collective authorship, ephemeral production, genre, Macbeth, multilingualism, Shakespeare in India, tradaptation

\section{AUTHOR}

\section{SARBANI CHAUDHURY}

University of Kalyani, West Bengal (India) 